
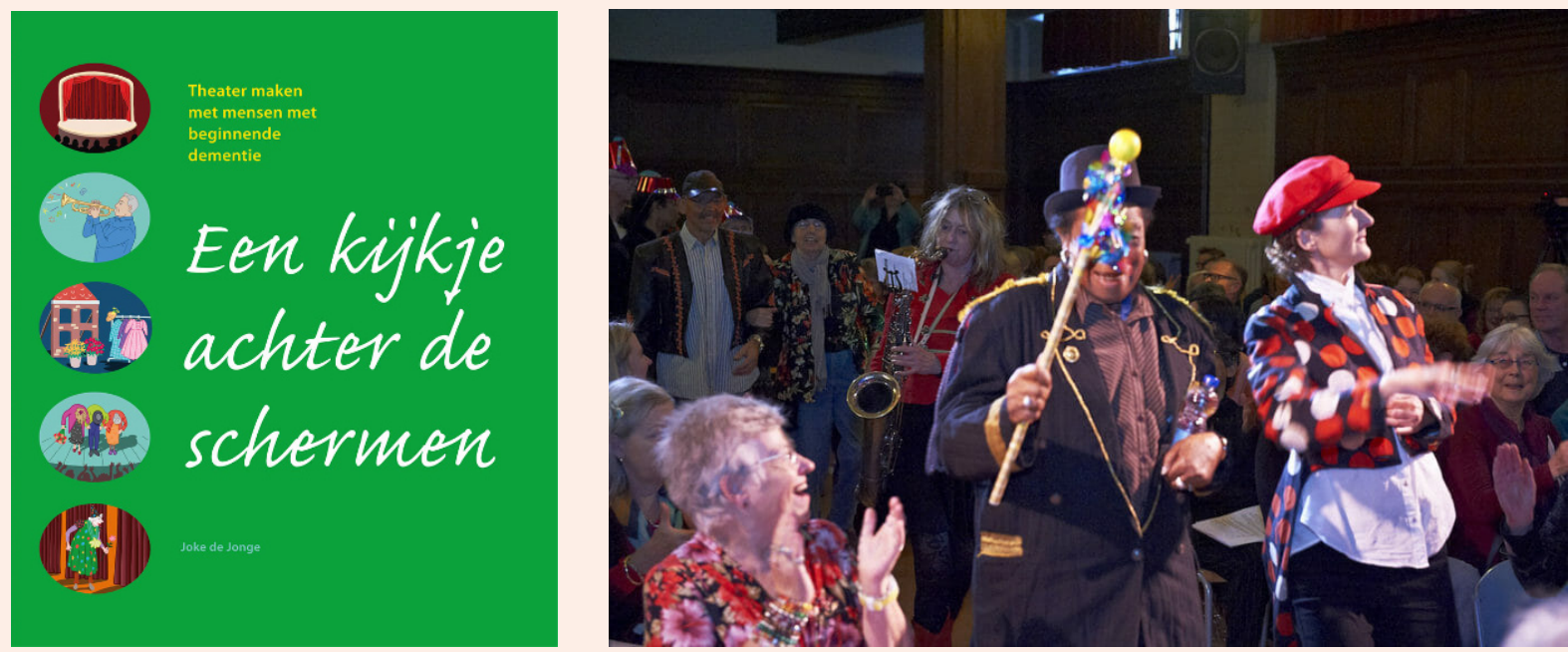

\title{
Mensen met dementie op de planken
}

$\mathbf{M}$ ensen met beginnende dementie kunnen zelf prachtig theater spelen.

Als je hún mogelijkheden maar als uitgangspunt van een voorstelling neemt en daar steeds improviserend op inspeelt. En als je er vooral maar heel ruim de tijd voor neemt en zorgt voor wat zíj nodig hebben om overtuigend te kunnen spelen. Dat is de les van de voorstelling Ontmoet ELKander en de boodschap van het boek Een kijkje achter de schermen.

Met het theaterstuk Ontmoet ELKander ondernam het Odensehuis Amsterdam-Zuid in 2017 een geweldige ontdekkingsreis. Voor zover bekend was het een primeur: de eerste keer dat mensen met beginnende dementie zelf met een theaterproductie op de planken stonden. Terwijl een verteller het publiek meenam naar een locatie, beeldden de spelers overtuigend een bepaalde situatie met bijpassende sfeer uit. Gevarieerde muziek en aansprekende zang ondersteunden de scènes. Het geheim achter deze wereldprimeur: uitgaan van wat mensen met dementie allemaal kunnen, hun talenten opsporen en hen aanmoedigen die weer te laten zien. Met theater kun je sluimerende talenten (opnieuw) tot leven laten komen. Haal naar boven wat mensen vroeger graag deden en laat ze daarin weer schitteren, is het devies van het Odensehuis. Dat zag je terug in de voorstelling. Een vroegere ober die als zodanig aan een beweging te herkennen was, liep als vanouds te serveren toen hij borden kreeg aangereikt. Een vrouw die jarenlang als clown optrad kwam er door het opzetten van een rode neus toe haar koffer met clownskleren van zolder te halen en speelde een glansrol. Zelfs een wervelend tangopaar diende zich aan. Begeleid door een live strijkerstrio deed het duo een golf van ontroering door de zaal gaan.

\section{INSPIRATIEBRON}

Wat zijn de ingrediënten voor een boeiende voorstelling en hoe krijg je zo'n project van de grond? Waar moet je rekening mee houden als je werkt met mensen met beginnende dementie? Welke reacties en belemmeringen kun je tegenkomen en hoe ga je daarmee om? Het zijn vragen die aan de orde komen in Een kijkje achter de schermen. Theater maken met mensen met beginnende dementie, een methodiekboek voor wie op theatergebied actief iets wil ondernemen met mensen met dementie.

Actieve betrokkenheid bij de voorbereiding van de voorstelling Ontmoet ELKander vormde de inspiratiebron voor dit boek. Behalve het verhaal over wat zich allemaal achter de schermen afspeelde, bevat de publicatie talloze adviezen en praktische tips, interviews met vakmensen op het gebied van theater en dementie, indrukken van spelers, muzikanten, zangers en publiek en een praktisch 'Aan de slag'. Het fotomateriaal laat het plezier zien dat de spelers aan dit gezamenlijke project beleefden. De conclusie: mensen met beginnende dementie kunnen meer dan zijzelf en de buitenwereld denken. Als je openstaat voor hun mogelijkheden en met hen meebeweegt, gaat er een bijzondere wereld voor je open.

TEKST JOKE DE JONGE

BEELD KEES VAN DER MEULEN

Joke de Jonge is zelfstandig ondernemer en schrijver. Meer informatie: www.dementieleeslijn.nl. Joke de Jonge (2018). Een kijkje achter de schermen. Theater maken met mensen met beginnende dementie. Amsterdam: Uitgeverij SWP, 96 p., $€ 24,90$. 